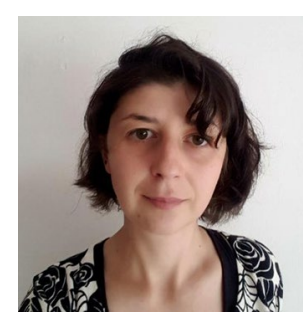

Credit: Adriana Rudling

\title{
Now is the time to reassess fieldwork-based research
}

\author{
Fieldwork-based research by non-local scholars is valued in social science, but the COVID-19 \\ pandemic has highlighted the exclusionary mechanisms and power differentials that sustain \\ such research. This must change, writes Adriana Rudling.
}

F ieldwork has been depicted as the holy grail of social sciences. Field visits are a means for researchers to access locally produced documental evidence and the lived experiences of research participants in their most immediate form. Being physically removed from the field, even temporarily, has been understood traditionally as a way of reducing research bias and gaining in objectivity. It is an opportunity for the researcher to reflect on their experiences, the data collection process, and findings, particularly the 'messier' aspects of this process, without 'undue' influence from the context where it was produced. This includes, but is not restricted to, research participants with self-serving interests.

Furthermore, remoteness is part of the very fabric of some sub-disciplines that broadly fit under the social sciences umbrella, like peace and conflict research. Massive and systematic human rights violations, for instance, have been studied by academics in the Global North as a phenomenon linked particularly with civil and political unrest in the Global South. If you consider the potential vulnerability to harm of scholars who openly oppose authoritarian governments and practices from within, it becomes clear that distance may be a must. But you do not need to go that far: consider how the patchy delivery of public service goods, such as electricity or Internet access, that is often the case in (post-)transitional societies dealing with large-scale human rights violations can affect the ability of local or locally based scholars to produce research on these matters. Remoteness, in this sense, has given researchers in this sub-field a 'safe place' from whence to enunciate the harms visited upon their research participants and advocate on their behalf.

As Arundhati Roy has written ${ }^{1}$, we can consider the COVID-19 health crisis " $a$ portal" as it has increasingly called into question a number of dimensions, marking a before and after for (non-)human life. To better understand what COVID-19 has meant for fieldwork-based research and the relationship between the Global North and Global South scholars, I want to draw your attention to a poem ${ }^{2}$ entitled "I am not your data" by Abhay Xaxa, an Adivasi rights activist and sociologist by training. Xaxa passed away unexpectedly of a heart attack in March 2020, a few days after the World Health Organization declared the COVID-19 health crisis a pandemic, and his poem was widely circulated on social media throughout 2020. Despite being written a few years prior, the most striking verse of this ode to epistemic justice and decolonial research methodologies remains, "Nor am I the lab where your theories are tested." As the spread of the COVID-19 virus gradually brought the world to a standstill and the death toll climbed into the millions, the rumour that pharmaceutical companies based in the Global North would test the vaccines in the Global South, specifically in several African countries, began to take hold. This consolidated the poem's underlying narrative about the nature of fieldwork and the research relationship between the Global North and the Global South. Because of the (perceived) widespread human rights violations taking place in the Global South, but also because of the power differential between the two spaces, the use of the Global South as "the lab" for Global North theories has been more common than many would like to admit.

To give a recent example, in 2010 the US apologized for syphilis experiments carried out in Guatemala during the 1940s, in which hundreds of prisoners and mental health patients were purposely, but covertly, infected. Susan M. Reverby, a Wellesley College professor whose work focused primarily on the history of US health care provision, uncovered evidence of these unethical and cruel practices in US archives. Between 1946 and 1948, when the experiments were carried out, Guatemala underwent a number of overlapping coups and constitutional crises punctuated by massive human rights violations. While the internal political commotion does not excuse the Guatemalan government for its human rights obligations, such as they were in the 1940s, it further highlights the question about the true capacity of the Global South, researchers included, to withstand pressures from the Global North.
The final lines of Xaxa's poem remind us of his extratextual commitment as an activist and a member of the Adivasi ethnic group. Xaxa lays an unequivocal claim to his right as a scholar and activist to "draw [his] own picture" and "make [his] own tools to fight [his] own battle." In the division of labour pertaining to fieldwork-based research, work produced in the Global North that leverages local knowledge and expertise from the Global South is celebrated for its 'authenticity' or 'richness'. But locally based researchers and activists who transition to scholarly work continue to be regarded with some suspicion due to 'unresolved' questions about objectivity. Since COVID-19 vaccines have become available, we have seen the power differential between the Global North and the Global South play out in a different way in fieldwork-based research: while travel has been made possible again for researchers situated in the Global North, civil and political unrest is growing in the Global South, where activists and researchers alike continue to face the multiple precarities associated with the health crisis. If we take Roy's advice seriously as researchers, we must seriously engage with the deficits of fieldwork-based research as we walk through the COVID-19 portal. This means we must question the research-activism and Global North-Global South divides as overlapping exclusionary mechanisms operating in our epistemic communities.

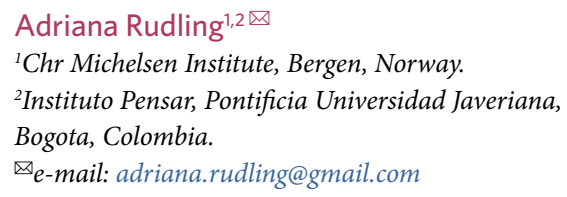

Published online: 22 June 2021 https://doi.org/10.1038/s41562-021-01157-x

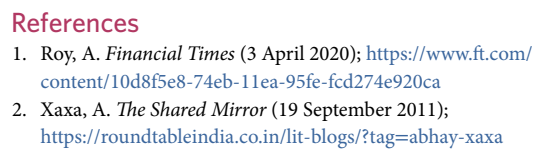

Competing interests

The author declares no competing interests. 